\title{
III. CASEINOGEN AND CASEIN.
}

\author{
By ARTHUR GEAKE. \\ From the Bio-Chemical Laboratory, Chemical Department, \\ University of Bristol. \\ (Received November 29th, 1913.)
}

The question of the chemical identity of caseinogen and casein and with it, of the nature of rennet action, still remains open in spite of many attempts at a solution. Hammarsten suggested that by the action of rennet, caseinogen was hydrolysed to form two new proteins, casein and whey-protein. Köster [1881] analysed these proteins and found that casein contained somewhat more nitrogen $(15.84 \%$ ) than caseinogen and whey-protein much less $(13 \cdot 1-13 \cdot 6 \%)$. On the other hand it has been suggested that rennet action is either purely physical or is only concerned with the inorganic constituents of milk and that casein is chemically identical with caseinogen. During the progress of this work a new suggestion has been put forward by van Slyke and Bosworth [1913], according to whom caseinogen is split by rennet into two molecules of casein.

If Hammarsten's theory is correct, it should be possible to find some chemical differences between caseinogen and casein. Elementary analyses have yielded the following results:-

\begin{tabular}{|c|c|c|c|c|c|}
\hline Caseinogen & $\mathbf{C}$ & H & $\mathbf{N}$ & $\mathbf{S}$ & $\mathbf{P}$ \\
\hline Makris [1876] & $53 \cdot 02$ & $7 \cdot 42$ & $14 \cdot 20$ & - & - \\
\hline Hammarsten [1883-1885] & $52 \cdot 96$ & $7 \cdot 05$ & $15 \cdot 65$ & $0 \cdot 758$ & $0 \cdot 347$ \\
\hline Chittenden \& Painter [1887] & $53 \cdot 3$ & $7 \cdot 07$ & $15 \cdot 91$ & 0.82 & $0.84-0.89$ \\
\hline Lehmann \& Hempel [1894] & $\mathbf{5 4} \cdot 0$ & $7 \cdot 04$ & $15 \cdot 6$ & 0.771 & 0.847 \\
\hline Ellenberger [1902] & $53 \cdot 07$ & $7 \cdot 13$ & $15 \cdot 64$ & $0 \cdot 76$ & 0.8 \\
\hline Laqueur \& Sackur [1903] & - & - & $15 \cdot 45$ & $0 \cdot 757$ & $0 \cdot 772$ \\
\hline Burow [1905] & $52 \cdot 825$ & $7 \cdot 095$ & $15 \cdot 64$ & $0 \cdot 725$ & 0.808 \\
\hline Tangl [1908] & $52 \cdot 69$ & $6 \cdot 81$ & $15 \cdot 65$ & 0.832 & 0.877 \\
\hline van Slyke \& Bosworth [1913] & $53 \cdot 50$ & $7 \cdot 13$ & $15 \cdot 80$ & $0 \cdot 72$ & 0.71 \\
\hline Mean & $53 \cdot 17$ & $7 \cdot 09$ & $15 \cdot 67$ & $0 \cdot 768$ & 0.82 \\
\hline Casein & & & & & \\
\hline Köster [1881] & - & - & $15 \cdot 84$ & - & - \\
\hline Rose \& Sohulze [1885] & 53.94 & $7 \cdot 14$ & $15 \cdot 14$ & 1.01 & - \\
\hline Raudnitz [1904] & - & - & $15 \cdot 5$ & 一 & $0 \cdot 7-0.88$ \\
\hline Kikkoji [1909] & - & - & - & - & $0.85-0.87$ \\
\hline an Slyke \& Bosworth [ & $\mathbf{5 3 \cdot 5 0}$ & $\mathbf{7 \cdot 2 6}$ & $15 \cdot 80$ & 0.72 & 0.71 \\
\hline Mean & $53 \cdot 72$ & $7 \cdot 20$ & $15 \cdot 57$ & 0.87 & 0.79 \\
\hline
\end{tabular}


The only reliable analysis of casein is that of van Slyke and Bosworth [1913] who obtained identical results for caseinogen and casein. They have also obtained somewhat more sulphur than phosphorus, which is in agreement with the supposition that there are equal numbers of atoms of these two elements in the molecules of these proteins.

The object of the following investigation was to determine the difference, if any, between caseinogen and casein both in elementary composition and in Hausmann numbers.

Most of the nitrogen estimations quoted above have been carried out by Kjeldahl's method and are thus inclined to be too low. The author has made estimations both by Kjeldahl's and by Dumas' method. Sulphur estimations are usually carried out by one of the various fusion methods described in the literature. These all lead to the precipitation of barium sulphate in the presence of comparatively excessive amounts of alkali salts, usually chlorides. It has however been shown by Allen and Johnston [1910] and Johnston and Adams [1911] that the presence of even relatively small amounts of such salts destroys the accuracy of sulphate estimations. This source of error has been avoided in the analyses described below by adopting a slight modification of Carius' method.

The following mean results were obtained for caseinogen and casein :-

$\begin{array}{lcc} & \text { Caseinogen } & \text { Casein } \\ & \% \% & \% \\ \text { C } & 53 \cdot 20 & 53 \cdot 05 \\ \text { H } & 7 \cdot 09 & 7 \cdot 03 \\ \text { N (Dumas) } & 15 \cdot 63 & 15 \cdot 81 \\ \text { N (Kjeldahl) } & 15 \cdot 61 & 15 \cdot 62 \\ \text { S } & 1 \cdot 015 & 1 \cdot 009 \\ \text { P } & 0 \cdot 731 & 0.809\end{array}$

The results for sulphur are higher than have been previously obtained for caseinogen. It will be seen above that Rose and Schulze [1885] obtained $1.01 \%$ sulphur in casein in agreement with the author's result. The sulphur contents of caseinogen and casein appear to be identical, but casein apparently contains more phosphorus than caseinogen. The difference is however not sufficient to warrant the supposition that the two proteins are chemically different.

As will be seen from the following figures the Hausmann numbers for the two proteins are also too close to establish any definite difference.

\begin{tabular}{|c|c|c|}
\hline & $\begin{array}{l}\text { Caseinogen } \\
\% \text { total } \mathrm{N}\end{array}$ & $\begin{array}{l}\text { Casein } \\
\% \text { total } \mathrm{N}\end{array}$ \\
\hline Ammoniacal N & $10 \cdot 23$ & $10 \cdot 31$ \\
\hline Melanin N & $1 \cdot 53$ & 1.66 \\
\hline Diamino N & $22 \cdot 94$ & $24 \cdot 03$ \\
\hline Monamino $\mathrm{N}$ & $65 \cdot 31$ & 63.90 \\
\hline & $100 \cdot 01$ & $99 \cdot 90$ \\
\hline
\end{tabular}




\section{A. GEAKE}

Osborne and Harris [1903] obtained from caseinogen

\begin{tabular}{lr} 
& $\%$ total N \\
Ammoniacal N & $10 \cdot 31$ \\
Melanin N & $1 \cdot 34$ \\
Diamino N & $22 \cdot 34$ \\
Monamino N & $66 \cdot 01$ \\
\hline & $100 \cdot 00$
\end{tabular}

with which the author's results are in substantial agreement.

\section{EXPERIMENTAL PART.}

\section{ELEMENTARY :ANALYSIS OF CASEINOGEN AND CASEIN.}

The caseinogen used was Kahlbaum's "Casein nach Hammarsten" carefully freed from fat by prolonged extraction in a Soxhlet apparatus with ether.

The casein was prepared from milk by the action of rennet and purified by Hammarsten's method. The last traces of fat were removed as above. Two specimens were separately prepared and analysed.

Before analysis the samples were allowed to stand at least 16 hours exposed to the air of the balance room, and when each portion was weighed out for an estimation a second portion was taken and dried to constant weight at $40^{\circ}$ in vacuum over $\mathrm{P}_{2} \mathrm{O}_{5}$ and the results corrected for the percentage of water thus found. It was found impossible to handle the very hygroscopic dry proteins with any certainty of accuracy. The ash was also estimated and allowed for. All the results are calculated for the ash-free dry proteins.

Carbon and hydrogen estimations were carried out in an ordinary combustion tube filled with alternate layers of copper oxide and lead chromate. The substance in the boat was covered with a mixture of lead chromate and potassium bichromate.

Nitrogen estimations were carried out both by Kjeldahl's and by Dumas' method.

Sulphur was estimated by the following modification of the Carius method. About $0.5 \mathrm{grm}$. of the protein was heated in a sealed tube with 7-8 cc. fuming nitric acid for two days at $300^{\circ}$. After opening the tube the contents were diluted and filtered and the filtrate treated with a slight excess of barium chloride over that required to combine with the sulphuric and phosphoric acids. No precipitate was obtained. The solution was evaporated to dryness, a few cc. of concentrated hydrochloric acid added and again evaporated to dryness completely to remove the nitric acid. The residue 
was taken up with $50 \mathrm{cc}$. of water and $2 \cdot 2$ or $4.5 \mathrm{cc}$. of dilute $(6.5 \%)$ hydrochloric acid added. The barium sulphate was thus obtained in a granular condition. It was collected on a layer of " $\mathrm{BaSO}_{4}$ asbestos" in a Gooch crucible, washed and dried in an air oven at 110-120 to constant weight. From Allen and Johnston's [1910] results the following corrections were made for the solubility of barium sulphate :-

$2 \cdot 2$ cc. dilute $\mathrm{HCl}$ add $0.5 \mathrm{mgm}$. $\mathrm{BaSO}_{4}$.

4.5 cc. dilute $\mathrm{HCl}$ add $0.6 \mathrm{mgm}$. $\mathrm{BaSO}_{4}$.

Phosphorus was estimated in the filtrate from $\mathrm{BaSO}_{4}$ by Gregerson's [1907] modification of Neumann's [1900] method.

Caseinogen.

Ash $\left\{\begin{array}{l}0.5764 \\ 0.5750\end{array}\right\}=0.57 \%$ except where otherwise stated.

C \& $\mathrm{H} 0.2118 \mathrm{~g}$. containing $10.30 \% \mathrm{H}_{2} \mathrm{O} ; 0.3690 \mathrm{~g} . \mathrm{CO}_{2} ; 0.1403 \mathrm{~g} . \mathrm{H}_{2} \mathrm{O}$.

0.2214 g. $\quad, \quad 6.54 \% \mathrm{H}_{2} \mathrm{O} ; 0.4010 \mathrm{~g} . \mathrm{CO}_{2} ; 0.1492 \mathrm{~g} . \mathrm{H}_{2} \mathrm{O}$.

$0.2415 \mathrm{~g} . \quad, \quad 6.54 \% \mathrm{H}_{2} \mathrm{O} ; 0.4377 \mathrm{~g} . \mathrm{CO}_{2} ; 0.1549 \mathrm{~g} . \mathrm{H}_{2} \mathrm{O}$.

$\mathrm{N}$ (Dumas) 0.2227 g. containing $6.54 \% \mathrm{H}_{2} \mathrm{O} ; 27 \cdot 2$ cc. nitrogen over $50 \% \mathrm{KOH}$ at $15 \cdot 5^{\circ} \mathrm{C}$. and $760 \mathrm{~mm}$.

$\mathrm{N}\left(\mathrm{Kj}\right.$ jeldahl) $\mathrm{Ash}=\left\{\begin{array}{l}0.32 \\ 0.20\end{array}\right\}=0.26 \% ; \mathrm{H}_{2} \mathrm{O}=11 \cdot 30 \%$.

$0 \cdot 2510$ g. required $24 \cdot 63$ cc. $\mathrm{N} / 10 \mathrm{H}_{2} \mathrm{SO}_{4}$.

$0 \cdot 2494 \mathrm{~g}$. , $24 \cdot 72 \mathrm{cc}$. ...,

$0 \cdot 2507$ g. , $24 \cdot 66$ cc. ,

$0.2493 \mathrm{~g}$. , $24.43 \mathrm{cc}$.,

S 0.5008 g. containing $7 \cdot 69 \% \mathrm{H}_{2} \mathrm{O} ; 0.0332 \mathrm{~g}$. $\mathrm{BaSO}_{4}$.

$0.5055 \mathrm{~g}$.,$\quad 7.69 \% \mathrm{H}_{2} \mathrm{O} ; 0.0354 \mathrm{~g} . \mathrm{BaSO}_{4}$.

P 0.4936 g. containing $7.69 \% \mathrm{H}_{2} \mathrm{O}$ required 29.61 cc. $\mathrm{N} / 10 \mathrm{NaOH}$.

0.5055 g. , $\quad 7 \cdot 69 \% \mathrm{H}_{2} \mathrm{O}, \quad, \quad 30 \cdot 71 \mathrm{cc}$.

Ash-free dry caseinogen :

$\begin{array}{lllcc}\text { C=53.25, 53.15, } 53 \cdot 20 & \ldots & \ldots & 53 \cdot 20 \% \\ \text { H=7.03, 7.32, 6.93 } & \ldots & \ldots & \ldots & 7 \cdot 09 \\ \text { N (Dumas) }=15 \cdot 63 & \ldots & \ldots & \ldots & 15 \cdot 63 \\ \text { N (Kjeldahl) }=15 \cdot 54, & 15 \cdot 76, & 15 \cdot 61, & 15 \cdot 54 & 15 \cdot 61 \\ \text { S }=0 \cdot 992,1 \cdot 048 & \ldots & \ldots & \ldots & 1 \cdot 015 \\ \text { P }=0.727,0.734 & \ldots & \ldots & \ldots & 0 \cdot 731\end{array}$

Casein (Prep. I).

Ash $=0.31 \%$ of dry casein.

$\mathrm{C} \& \mathrm{H} 0 \cdot 2408 \mathrm{~g}$. containing $11 \cdot 75 \%$ water; $0 \cdot 4133 \mathrm{~g} . \mathrm{CO}_{2} ; 0 \cdot 1576 \mathrm{~g} . \mathrm{H}_{2} \mathrm{O}$.

0.2040 g., $11 \cdot 70 \%$ water; $0.3493 \mathrm{~g} . \mathrm{CO}_{2} ; 0 \cdot 1390 \mathrm{~g} . \mathrm{H}_{2} \mathrm{O}$.

$\mathrm{N}$ (Dumas) $0.2792 \mathrm{~g}$. containing $11.75 \%$ water; $33.6 \mathrm{cc}$. nitrogen over water at $1 \ddot{z}^{\circ} \mathrm{C}$. and $742 \mathrm{~mm}$.

$0.3342 \mathrm{~g}$. containing $11 \cdot 70 \%$ water ; $40.0 \mathrm{cc}$. nitrogen over water at $15 \cdot 3^{\circ} \mathrm{C}$. and $749 \mathrm{~mm}$.

S $0.5063 \mathrm{~g}$. containing $11 \cdot 75 \%$ water; $0.0323 \mathrm{~g}$. $\mathrm{BaSO}_{4}$.

$0.4939 \mathrm{~g}$. , $10.09 \%$ water; $0.0295 \mathrm{~g}$. $\mathrm{BaSO}_{4}$.

0.4250 g. dry casein; 0.0312 g. $\mathrm{BaSO}_{4}$.

$P 0.5063$ g. containing $11.75 \%$ water required 33.33 cc. $\mathrm{N} / 10 \mathrm{NaOH}$.

0.4939 g. " $10.09 \%, ", \quad 32 \cdot 30$ cc. N/10 NaOH.

Bioch. vIII 
Dry ash-free casein (Prep. I):

Mean

$$
\begin{array}{lrrrr}
\mathbf{C}=53 \cdot 21,53 \cdot 06 & \ldots & \ldots & \ldots & 53 \cdot 14 \% \\
\mathrm{H}=6 \cdot 82, \mathbf{7 \cdot 1 7 \ldots} & \ldots & \ldots & \ldots & 7 \cdot 00 \\
\mathrm{~N} \text { (Dumas) }=15 \cdot 85, \mathbf{1 5} \cdot 68 & \ldots & \ldots & 15 \cdot 77 \\
\mathrm{~S}=0.999,(0.919), & 1.008 & \ldots & \ldots & 1.004 \\
\mathrm{P}=0.829,0.809 & \ldots & \ldots & \ldots & 0.819
\end{array}
$$

Casein (Prep. II).

$$
\text { Ash }=0.45 \% \text { of dry casein. }
$$

$\mathrm{C} \& \mathrm{H} 0.2268 \mathrm{~g}$. containing $11.95 \%$ water; $0.3867 \mathrm{~g} . \mathrm{CO}_{2} ; 0.1539 \mathrm{~g} . \mathrm{H}_{2} \mathrm{O}$. $0.2127 \mathrm{~g}$.,$\quad 11.94 \%$ water $; 0.3616 \mathrm{~g} . \mathrm{CO}_{2} ; 0.1413 \mathrm{~g} . \mathrm{H}_{2} \mathrm{O}$.

$\mathrm{N}$ (Dumas) $0.2487 \mathrm{~g}$. containing $11.95 \%$ water ; $30 \cdot 1 \mathrm{cc}$. nitrogen over water at $17 \cdot 2^{\circ} \mathrm{C}$. and $754 \mathrm{~mm}$.

0.2886 g. containing $11.94 \%$ water; $33.7 \mathrm{cc}$. nitrogen over $50 \%$ potash at $15 \cdot 7^{\circ} \mathrm{C}$. and $756 \mathrm{~mm}$.

S $0.5318 \mathrm{~g}$. containing $11.94 \%$ water; $0.0340 \mathrm{~g}$. $\mathrm{BaSO}_{4}$.

$0.5154 \mathrm{~g} . \quad, \quad 11.94 \%$ water; $0.0337 \mathrm{~g} . \mathrm{BaSO}_{4}$.

$P$ 0.5318 g. containing $11.94 \%$ water required 34.05 cc. N/10 NaOH.

$0.5154 \mathrm{~g}$. $, \quad 11.94 \% \quad, \quad, \quad 32.08 \mathrm{cc}$

Dry ash-free casein (Prep. II) :

Mean

$\begin{array}{lllll}\mathbf{C}=53 \cdot 02,52 \cdot 88 & \ldots & \ldots & \ldots & 52.95 \%\end{array}$

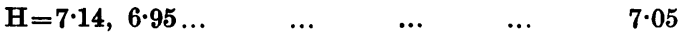

$\mathrm{N}($ Dumas) $=15 \cdot 88,15 \cdot 81 \quad \ldots \quad \ldots \quad \ldots \quad 15 \cdot 85$

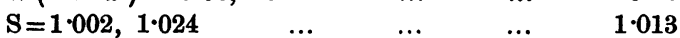

$\begin{array}{lllll}\mathrm{P}=0.810,0.787 & \ldots & \ldots & \ldots & 1 . \\ & \ldots & \ldots & \ldots & 0.799\end{array}$

Kjeldahl nitrogen estimations of casein were carried out with a third specimen prepared by the same method.

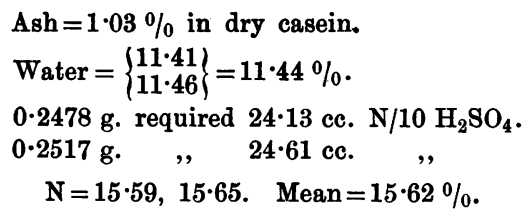

The mean compositions of caseinogen and casein are thus :-

$\begin{array}{lcc} & \text { Caseinogen } & \text { Casein } \\ & \% \% & \% \\ \text { C } & 53 \cdot 20 & 53 \cdot 05 \\ \text { H } & 7 \cdot 09 & 7 \cdot 03 \\ \text { N (Dumas) } & 15 \cdot 63 & 15 \cdot 81 \\ \text { N (Kjeldahl) } & 15 \cdot 61 & 15 \cdot 62 \\ \text { S } & 1 \cdot 015 & 1009 \\ \text { P } & 0 \cdot 731 & 0 \cdot 809\end{array}$

Hausmann Numbers.

The caseinogen used was Kahlbaum's "Casein nach Hammarsten." The ash and water were estimated and allowed for as above. 
Three samples of casein were used.

(1) Prepared by the action of rennet on a solution of caseinogen in disodium hydrogen phosphate. The casein was precipitated by calcium chloride and purified by Hammarsten's method.

(2) and (3) Prepared by the action of rennet on a solution of caseinogen in the minimum amount of $\mathrm{NaOH}$. The rennet was destroyed by heating momentarily to $90^{\circ} \mathrm{C}$. with steam and the casein precipitated with glacial acetic acid. It was purified by Hammarsten's method. At each purification after the first a portion was washed with alcohol and ether and not further purified. In this way four fractions were obtained.

From 110 g. air-dry (about 100 g. dry) caseinogen were obtained :-

\begin{tabular}{|c|c|c|c|}
\hline \multirow{3}{*}{\multicolumn{2}{|c|}{ Fraction }} & $\begin{array}{l}\text { Prep. (2) } \\
\text { g. }\end{array}$ & $\begin{array}{l}\text { Prep. (3) } \\
\text { g. }\end{array}$ \\
\hline & & 12 & 13 \\
\hline & $b$ & 11 & 16 \\
\hline & $c$ & 13 & 12 \\
\hline \multirow{2}{*}{\multicolumn{2}{|c|}{ 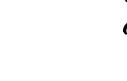 }} & 14 & 11 \\
\hline & & 50 & 52 \\
\hline
\end{tabular}

The fractions (2) $a,(2) d,(3) b$ and (3) $d$ were used for Hausmann numbers.

The Hausmann numbers were estimated by the method given by Röhmann [1908]. Usually the diamino nitrogen was estimated in the phosphotungstic acid precipitate and the monamino nitrogen in the filtrate from this, in some cases only one of these two was estimated and the other obtained by difference. Figures thus obtained by difference are given below in brackets. The results are given in percentages of the total nitrogen obtained by addition of the four separate nitrogen percentages.

Caseinogen.

1 st Series.

Ammoniacal
Melanin N
Diamino N
Monamino N
2nd Series.

Ammoniacal N

Melanin N

Diamino $\mathrm{N}$

Monamino N

$$
10 \cdot 52
$$

$1 \cdot 79$

$(23 \cdot 07)$

$64 \cdot 62$

$(2)$
$10 \cdot 64$
$0 \cdot 58$
$(26 \cdot 19)$
$62 \cdot 59$

\begin{tabular}{r}
\multicolumn{1}{c}{$(3)$} \\
$10 \cdot 06$ \\
$2 \cdot 07$ \\
$20 \cdot 00$ \\
$67 \cdot 87$
\end{tabular}

(7)

$10 \cdot 35$

$1 \cdot 57$

$23 \cdot 77$

$64 \cdot 31$

\begin{tabular}{rr}
$(4)$ & Mean \\
$9 \cdot 73$ & $10 \cdot 24$ \\
$1 \cdot 57$ & $1 \cdot 50$ \\
20.92 & $22 \cdot 55$ \\
$67 \cdot 78$ & $65 \cdot 72$ \\
\cline { 2 - 2 } & $100 \cdot 01$
\end{tabular}

(8)

$10 \cdot 26$

$1 \cdot 59$

$22 \cdot 98$

$65 \cdot 23$

\begin{tabular}{rr}
\multicolumn{1}{c}{$(9)$} & Mean \\
$10 \cdot 17$ & $10 \cdot 23$ \\
$1 \cdot 71$ & $1 \cdot 55$ \\
$23 \cdot 56$ & $23 \cdot 25$ \\
$64 \cdot 57$ & $64 \cdot 99$ \\
\hline & $100 \cdot 02$
\end{tabular}


Casein (Prep. (1)).

\begin{tabular}{|c|c|c|c|c|c|}
\hline & (1) & (2) & (3) & (4) & Mean \\
\hline Ammoniacal $\mathrm{N}$ & $9 \cdot 92$ & $10 \cdot 38$ & $10 \cdot 26$ & $10 \cdot 51$ & $10 \cdot 27$ \\
\hline Melanin N & $1 \cdot 50$ & $1 \cdot 57$ & $1 \cdot 63$ & $1 \cdot 37$ & 1.52 \\
\hline Diamino $N$ & $(23 \cdot 89)$ & $(25 \cdot 59)$ & $24 \cdot 05$ & $(23 \cdot 96)$ & $24 \cdot 37$ \\
\hline Monamino N & $64 \cdot 69$ & $62 \cdot 46$ & $64 \cdot 07$ & $64 \cdot 16$ & $63 \cdot 85$ \\
\hline
\end{tabular}

Casein (Prep. 2a).

\begin{tabular}{lcrcr} 
& \multicolumn{1}{c}{$(1)$} & $(2)$ & $(3)$ & Mean \\
Ammoniacal N & $10 \cdot 78$ & $10 \cdot 38$ & $9 \cdot 87$ & $10 \cdot 34$ \\
Melanin N & $1 \cdot 46$ & $1 \cdot 43$ & $1 \cdot 49$ & $1 \cdot 46$ \\
Diamino N & $23 \cdot 94$ & $25 \cdot 14$ & $22 \cdot 18$ & $23 \cdot 75$ \\
Monamino N & $63 \cdot 82$ & $63 \cdot 05$ & $66 \cdot 48$ & $64 \cdot 45$ \\
\hline
\end{tabular}

Casein (Prep. $2 d$ ).

\begin{tabular}{lccccr} 
& $(1)$ & $(2)$ & $(3)$ & $(4)$ & Mean \\
Ammoniacal N & $9 \cdot 91$ & $10 \cdot 31$ & $10 \cdot 17$ & $10 \cdot 22$ & $10 \cdot 13$ \\
Melanin N & $1 \cdot 66$ & - & $2 \cdot 28$ & $2 \cdot 14$ & $2 \cdot 01$ \\
Diamino N & - & - & $25 \cdot 30$ & $(23 \cdot 40)$ & $24 \cdot 35$ \\
Monamino N & - & $62 \cdot 99$ & $62 \cdot 24$ & $64 \cdot 24$ & $63 \cdot 24$ \\
\cline { 2 - 5 }
\end{tabular}

Casein (Prep. 3 b).

(1) (2) (3)

\begin{tabular}{lccccr} 
& $(1)$ & $(2)$ & $(3)$ & $(4)$ & Mean \\
Ammoniacal N & $10 \cdot 42$ & $10 \cdot 29$ & $10 \cdot 55$ & $10 \cdot 69$ & $10 \cdot 49$ \\
Melanin N & $1 \cdot 59$ & $2 \cdot 00$ & $1 \cdot 51$ & $1 \cdot 64$ & $1 \cdot 69$ \\
Diamino N & $(28 \cdot 06)$ & $(20 \cdot 67)$ & $24 \cdot 66$ & $(24 \cdot 97)$ & $\mathbf{2 4} \cdot 60$ \\
Monamino N & $59 \cdot 92$ & $67 \cdot 04$ & $(63 \cdot 28)$ & $62 \cdot 70$ & $63 \cdot 28$ \\
\hline & & & & & $100 \cdot 02$
\end{tabular}

Casein (Prep. $3 d$ ).

\begin{tabular}{lrrr} 
& $(1)$ & $(2)$ & Mean \\
Ammoniacal N & $10 \cdot 65$ & $10 \cdot 00$ & $10 \cdot 33$ \\
Melanin N & $1 \cdot 65$ & $1 \cdot 70$ & $1 \cdot 68$ \\
Diamino N & $22 \cdot 47$ & $22 \cdot 11$ & $22 \cdot 29$ \\
Monamino N & $65 \cdot 23$ & $66 \cdot 19$ & $65 \cdot 71$ \\
\hline & & & $100 \cdot 01$
\end{tabular}

The mean of all the results gives the following values for caseinogen and casein :-

\begin{tabular}{lcc} 
& Caseinogen & Casein \\
Ammoniacal N & $10 \cdot 23$ & $10 \cdot 31$ \\
Melanin N & $1 \cdot 53$ & $1 \cdot 66$ \\
Diamino N & $22 \cdot 94$ & $24 \cdot 03$ \\
Monamino N & $65 \cdot 31$ & $63 \cdot 90$ \\
\cline { 2 - 3 } & $100 \cdot 01$ & $99 \cdot 90$
\end{tabular}




\section{Conclusions.}

The difference between caseinogen and casein is thus scarcely appreciable. If for caseinogen the second series alone is taken, the difference is still less than that given above. No difference could be established between the different fractions of casein.

In conclusion I wish to thank the University Colston Research Committee for a grant which defrayed most of the expenses of this work.

\section{REFERENCES.}

Allen and Johnston (1910), J. Amer. Chem. Soc. 32, 588.

Burow (1905), Inaug. Diss. Basel.

Chittenden and Painter (1887), Studies from the Yale University, 2, 156.

Ellenberger (1902), Arch. Anat. Physiol. Suppl. 313.

Gregerson (1907), Zeitsch. physiol. Chem. 63, 452.

Hammarsten (1883), Zeitsch. physiol. Chem. 7, 220.

- (1885), Zeitsch. physiol. Chem. 9, 273.

Johnston and Adams (1911), J. Amer. Chem. Soc. 33, 829.

Kikkoji (1909), Zeitsch. physiol. Chem. 61, 139.

Köster (1881), Biol. Centralbl. 2, No. 2; Maly's Jahresberichte, 11, 14.

Laqueur and Sackur (1903), Ergeb. d. Physiol. (Asher and Spiro), 2, Abt. I, 232.

Lehmann and Hempel (1894), Arch. ges. Physiol. 66, 558.

Makris (1876), Inaug. Diss. Strassburg.

Neumann (1900), Archiv Anat. u. Physiol. See also Zeitsch. physiol. Chem. 37 and 43.

Osborne and Harris (1903), J. Amer. Chem. Soc. 25, 323.

Raudnitz (1904), Monatsh. Kinderheilk. 2.

Röhmann (1908), Biochemie, p. 299.

Rose and Schulze (1885), Landw. Versuchsstat. 31, 115.

van Slyke and Bosworth (1913), J. Biol. Chem. 14, 203.

Tangl (1908), Pfliger's Archiv, 121, 534. 